\title{
How do Family Doctors Cure, Resolve, and Treat?
}

\section{Jose Luis Turabian}

Health Center Santa Maria de Benquerencia Toledo, Spain

*Corresponding author: Jose Luis Turabian, Health Center Santa Maria de Benquerencia Toledo, Spain, Tel: 34925154508; E-mail: jturabianf@hotmail.com

Received date: September 07, 2017; Accepted date: September 08, 2017; Published date: September 11, 2017

Copyright: @ 2017 Turabian JL. This is an open access article distributed under the terms of the Creative Commons Attribution License, which permits unrestricted use, distribution, and reproduction in any medium, provided the original author and source are credited

Keywords: Health; Cure; Health services for the aged; Family medicine; Terminal care; Therapeutics; Comprehensive health care, Multiple morbidity; Patient care planning

\section{Editorial}

The usual biomedical approach to "cure" is to consider that the family doctor does it by means of drugs, usually has a quantitative meaning ("90\% cases are resolved ..."), and it is considered dichotomous (cure-yes/no). But, the sense of healing/resolution is qualitative and occurs in a non-dichotomous continuum. Many diseases in Family Medicine are self-limited or have no cure, so it can be assumed that many of the medical pharmacological treatments are useless. The concept of healing or resolution should be seen in Family Medicine as facilitating the unlocking of a situation, change or move from one setting to another. It is the result of the action that gives rise to a new scenario. Healing takes place through the encounter of a person with other people (healing is a "relational" concept, of adjustment or change in the matrix of relationships or connections), rather than through interventions in the body or mind of the individual isolated. Healing involves in one way or another return of the part to the whole.

The prevalence of chronic diseases and the problems of aging in the population pose challenges to the current models of disease management and the end of life care. As age progresses, people face an increasing frequency to chronic and acute health problems that require medical attention. The ability of health care systems and family physicians to recognize and respond to acute health problems in chronic patients and the continued care of chronic diseases, and the use of a holistic understanding of health will play a central role in ensuring an effective and appropriate care, including care at the end of live [1-5]. Family doctors heal when are no stranger to the fear of patients, when have a solid notion of what it means to be a human being. The cure is due to the mere presence of the doctor-placebo effect, plus certain factors of the patient's own (desire or desire to live, beneficial role of positive emotions, trust in the doctor and cooperative work physician-patient). The tool/technology of family doctors is the doctor himself. For the patients to improve, the most important thing is that they like the doctor. If trust does not become an important part of this relationship, "healing" is unlikely to occur.

The physician-patient relationship model is a "context-creating" element. There are some non-specific effects of the patient-physician relationship in medical intervention: physicians who adopt a warm, friendly, and patient-friendly consultation are more effective in their interactions with patients than those who adopt a formal style and do not offer a friendly security. These more effective doctors take into consideration during the consultation the patient's health beliefs, his general opinions about medicine and specifically about the intervention of that moment, as well as the complexity of the socio- cultural effects. Healing is mainly about learning to receive a person with "pain." To do heal is to understand that one is involved in helping the other as a person, rather than as a scientist; that family doctor is involved with that person "in the dark." Family doctors heal when they are no stranger to the fear of patients; when have a solid notion of what it means to be a human being. While we "listen" to the patient can feel something very strange: we can felt her or his pain so intensely that, although the patient not could show it, the tears can crowd in ours eyes. "Heal" is to achieving a situation of interconnection. Core component of all interventions of family doctors is the interpersonal encounter between patient and therapist, in which sources of meanings are explored and a sense of connectedness is re-established [6].

Maybe together the patient and the doctor can understand the problem. What is on the table in the consultation is not the doctor or the patient, but the two together. The physician's task is to achieve and maintain a connection with the patient. Using our experience with suffering beings to connect with those who have crossed the border of what we call normality and try to bring them back to the flow of the human. The only way to overcome suffering and to turn it into joy is therefore to find its meaning. The suffering patient should, with the help of his inner wealth and that of the physician, be able to convert the sense of his pain into an ally; this will be without a doubt the greatest challenge of the person suffering from an illness. Keeping with the patient that connection of the type 'here, right now' in this suddenly and great moment. Like a father who learns not so much to hold a crying baby in his arms as to maintain the connection with that crying baby: a being with excessive tiredness, needing to be caught and cradled to sleep, a baby who can discern If the arms that support him, are twisted by anger or just try to control him, or are open and willing to be with he or she. If the arms are angry and trying to control it, the baby will fight. If the arms are relaxed and open, the baby will calm down and slide into sleep [7].

It is needed to seeing the patients from new perspectives. To seeing, not only his words, but also something else; everything that surrounds her or him and everything the space between us, just as in a field of wheat in the summer, that you can almost see the breeze that curls the wheat. Helping people has nothing to do with psychology, but with to be human with patient who suffers, to can advance with another person as the parts that form a whole. The successful results are not cures, but to having a function personally and socially in life to the extent that disease allows. The cure is not so much adjustment between the patient and his context, but to restore or reinforce the patient's ability to face his own problems, or to decide how to act in that situation here and now. Healing has to do with self-responsibility and training. A healthy person is not the one who is free of problems but the one who is able to deal with them. The healthy family/community are one that, when there are problems, supports those who carry more distress without blaming others for their difficulties [8]. And if we cannot heal, at least do not hurt them; we have to avoid creating more 
Citation: Turabian JL (2017) How do Family Doctors Cure, Resolve, and Treat?. J Gen Pract (Los Angel) 5: e118. doi:

Page 2 of 2

suffering around us. Healing can be to doing nothing. When the patient is a terminal, there are moments where it is best to do nothing: just be there. The physician's necessary skills are intuition, compassion, knowing our limits, courage, and integrity. So, the integration of palliative care and curative treatments are a rational approach to the care of people with advanced diseases and have been shown to reduce suffering, improve satisfaction, reduce costs and facilitate transitions between the different stages of progression of the illness $[9,10]$.

Family Medicine presents the unique opportunity to detect the transitions or "turning points" in healthcare (life cycle, trauma and stress, and "path" long-term) [11]. To fully understand the disease process, investigators and clinicians must consider the episodic and recurrent nature of disability. Disease in chronic patients have highest rates of transition from less to more disability, lower rates of transition from more to less disability, and longer durations of disability [12].

In conclusion, there is a lack of reflection, conceptualization and research on these issues. So, we would make the following suggestions of research:

- The concept of healing in Family Medicine (its systematization, description, distribution, measurement, etc.)

- Description, prevalence, associated factors, psychological, social, economic and spiritual aspects, clinical aspects, prevention, and public health implications about chronic and with multimorbidities patients $[13,14]$.

\section{References}

1. Turabian JL (2016) Musical clinical stories of family medicine. Developing the humanistic capacities of family doctors through art.
2. Batuman E (2016) Vladimir Nabokov, Butterfly illustrator. The New Yorker.

3. Turabian JL, Franco PB (2003) Notes on "resolving" and "cure" in family medicine. Aten Primaria 32: 296-299.

4. Moorhouse P, Koller K, Mallery L (2015) End of life care in frailty. Interdiscip Top Gerontol Geriatr 41: 151-160.

5. Anngwyn SJ (2007) Relative balance in an unstable world: A research on trauma education and recovery. Buenos Aires: Alma Lepik.

6. Torrelles GM, Royo MC, Prat RA, Sales PJ, Balaguer A (2017) Understanding meaning in life interventions in patients with advanced disease: A systematic review and realist synthesis. Palliat Med 1: 26.

7. Shem S (1997) Mount misery. Ivy books.

8. Steptoe A, de Oliveira C, Demakakos P, Zaninotto P (2014) Enjoyment of life and declining physical function at older ages: A longitudinal cohort study. CMAJ 186: E150-E156.

9. Ladha A, Sharma S, Batsis JA, Hanson GA, Swetz KM (2013) Care of the frail elder: The nexus of geriatrics and palliative care. Minn Med 96: 39-42.

10. Hall AJM, Higginson IJ (2002) Introduction. Palliative care for noncancer patients. Oxford University Press, New York.

11. Turabián JL, Franco PB (2016) Turning points and transitions in the health of the patients: A perspective from family medicine. J Family Med Community Health 3: 1087.

12. Hardy SE, Dubin JA, Holford TR (2005) Transitions between states of disability and independence among older persons. Am J Epidemiol 161: $575-584$

13. Turabián JL, Franco PB (2016) A way of helping "Mr. Minotaur" and "Ms. Ariadne" to exit from the multiple morbidity labyrinth: The "master problems". Semergen 42: 38-48.

14. Turabián JL, Franco PB (2014) Album of models for qualitative tools in the Family Medicine decision making. Other maps to describe a country. Semergen 40: 415-424. 